\title{
Do Institutions Really Matter? Assessing the Impact of State Judicial Structures on Citizen Litigiousness
}

\author{
Paul Brace \\ Clarence Carter Professor \\ Department of Political Science \\ Rice University \\ Houston, TX 77005 \\ Jeff Yates \\ Associate Professor \\ Holley Tankersley \\ Ph.D. Candidate \\ Department of Political Science \\ University of Georgia \\ Athens, GA 30602
}




\title{
Do Institutions Really Matter? Assessing the Impact of State Judicial Structures on Citizen Litigiousness
}

\begin{abstract}
$\underline{\text { Abstract }}$
The issue of American litigiousness, especially in the area of tort litigation, has long been a topic of academic debate and political consternation. While some researchers argue over the existence of a 'litigation explosion' or its extent, others seek to understand the root causes of citizen legal mobilization and why governmental entities (states, municipalities, etc.) often have very different experiences concerning citizen legal mobilization and rates of litigation. A number of explanations for variance in state litigation rates have been offered, including political culture, socio-economic dynamics, and legislative intervention (e.g. tort reform), among others. Some of these studies find that litigation and citizens' use of the courts provide an alternative means of political mobilization when more traditional means of political participation may be perceived as less viable. While such studies have provided important insight into citizens' propensity to invoke the state courts to settle disputes, there remain unresolved questions in the literature concerning state litigation rates. In addressing the puzzle of state legal mobilization, existing studies have largely ignored an important theoretical consideration: the institutional structure of state court systems. We draw upon a well-established state politics literature to argue that the structural aspects of state judicial systems, specifically the professionalism of the courts and the method of judicial selection, have important implications for state citizen legal mobilization (litigiousness). We further suggest that the effects of these institutional structural characteristics do not work independently, but are conditioned upon the ideology of the citizenry in which they operate. We consider tort litigation rates in 10 states over 20 years to assess the proposition that these institutional structural characteristics of state court systems affect state citizen legal mobilization, expressed as litigation rates.
\end{abstract}


Chief Justice Warren Burger once observed that mass neurosis leads people to think courts were created to solve all the problems of society (Burger 1985). Does America suffer from such a neurosis? Observers of political and legal culture continue to ponder questions about the litigiousness of contemporary American society. Whether it is referred to as the "adversary society," "adversarial legalism," or the "litigation explosion," the general phenomenon described in the literature involves concerns that Americans are increasingly using courts to resolve disputes and the growing perception that the nation is awash in frivolous lawsuits (e.g. Galanter 2002; Kagan 2002; Sarat 1985).

While some scholars lament the effects of rising litigation rates on American society and the national economy (e.g. Olsen 1991), others argue that any such effects must be balanced against the social utility of resultant consumer protections and advances in civil rights. Indeed, even the very existence of the "litigation explosion," or at least the extent of it, is subject to debate. Galanter and others argue that compared to other industrialized nations, such as England, Australia, or Denmark, the U.S. litigation rate is not particularly high (Galanter 1985, 2002; Glick 2004). Similarly, litigation rates in America are no higher today than they were during certain periods of the nineteenth and early twentieth century (Galanter 2002).

Beyond the current debate on the existence or extent of an American litigation explosion lies the underlying discord over the efficacy of legal mobilization as an appropriate avenue for political and social change. While litigation has had a prominent role in promoting the progress of civil rights and other laudable social causes, observers are concerned with citizens' invocation of the court system to deal with a myriad of personal and public matters. Additional concerns center on the redistribution of assets that is often involved in the resolution of such legal disputes.

The topic of tort litigation has been a particularly salient portion of this policy discussion. Lawsuits based in tort law typically involve "have nots" (individuals), seeking compensation from "haves" (businesses, insurance companies, etc.) for harms suffered due to the alleged malfeasance of the latter. It is this segment of litigation (as opposed to contract, property, or marital law claims) that has provoked the most political contention and has come to dominate debates on the claimed litigation explosion. While 
academics and policy specialists such as Galanter (1986, 1993, 1996) and Saks (1992) have both noted that concerns over a "tort crisis" are premature and argued that there has not been a significant rise in the propensity of Americans to bring tort lawsuits, the subject of tort litigation has been a hot button issue for politicians and legal commentators in recent decades. Without a doubt, the topics of tort litigation and tort reform legislation have been an integral part of both national and state political rhetoric, finding their way into national party platforms and presidential debates on the nation's civil justice system (Gasaway 2001; Haltom and McCann 2004). Further, the vast majority of state legislatures have heeded the appeals of business and interest groups to rein in the litigation explosion and have passed some form of tort reform (Schmit, Browne, and Lee 1997).

The controversy over American litigation rates has also seen the rise of a cottage industry of scholarly literature addressing the issue, with much of the discussion concentrating on tort lawsuits. A large portion of this literature has focused upon either proving or disproving the existence or extent of the litigation explosion (e.g. Galanter 1996). These studies generally present arguments based upon descriptive assessments of patterns of litigation rates, either over time or across jurisdictions. While such studies are often insightful, they do not systematically address the underlying question of what factors drive litigation rates.

A relatively limited, but informative literature has endeavored to make inroads towards explaining citizen legal mobilization and rates of litigation. Scholars have attempted to explain variation in rates of litigation, both over time and across jurisdictions, by investigating legal and extra-legal determinants of citizens' invocation of the court system (Daniels 1982; Grossman et al. 1982; Grossman and Sarat 1975; Harrington and Ward 1995; Marvel 1994; McIntosh 1983, 1990; Posner 1997; Roper 1986; Schmidt, Browne, and Lee 1997; Stookey 1986; Yates, Davis, and Glick 2001). Such studies have primarily drawn upon two broad theoretical orientations to account for differences in legal mobilization - political culture and social development. The first of these, political culture, concerns public norms and citizens' attitudes regarding the nature of politics and government and the proper usage of governmental institutions (Daniels 1982, 195). In contrast, social development theory posits that certain social, economic, and 
environmental characteristics of a society make its citizens prone to pursue litigation rather than more informal means of dispute resolution (Daniels 1982, 193). Studies employing these two primary theoretical orientations have met with varying success and empirical results have not always been very consistent. Some of this inconsistency is likely attributable to differences in studies' locus or time frame; however, a handful of scholars have taken this state of affairs as a cue to broaden the theoretical approach to account for institutional legal considerations (Harrington and Ward 1995; Posner 1997; Hanssen 1999; Yates et al. 2001).

While a government's legal milieu might involve specific legislative measures, such as tort reform, that are designed to affect citizens' access to judicial remedies or reward incentives, our interest lies in more fundamental aspects of state legal institutional development. We believe that differences in the elemental structure of the judicial system may affect the degree to which citizens invoke the legal system for redress. In this paper, we investigate the influence of two important structural aspects of state legal institutions. First, following a well-developed hypothesis in the literature we posit that states' methods of selecting judges may influence the degree to which citizens are disposed to using courts for the resolution of problems and grievances. Second, we suggest that the degree to which a state's court system is professionalized may either impede or promote citizen legal mobilization. Highly professionalized courts are characterized as having excellent work resources, higher pay, and relatively lighter workloads; these characteristics could indirectly influence litigation rates. Finally, we argue that the effects of these institutional structural characteristics do not work independently, but are conditioned upon the ideology of the citizenry in which they operate. In other words, the influence of judicial system structure is conditioned by the relative conservatism or liberalism of the citizenry.

Our study proceeds as follows. In the next section we set forth our approach to this research question and develop our primary hypothesis that state court institutional characteristics are linked to citizen legal mobilization. We further posit that this relationship turns upon the ideology of the electorate being served. In the section that follows, we describe our data, model specification, and discuss the results of the study. We conclude by offering observations on the implications of this study for understanding 
state institutional structure and its effects on legal mobilization.

\section{The Demand Side of Variation In Litigation Rates: The Role Of Institutions}

The conventional approaches to variation in tort litigation described above generally focus on factors reasoned to influence the supply of tort cases. Demographic and cultural characteristics of populations are reasoned to influence both the number of conflicts and common attitudes about litigation. The supply of potential cases, however, is only half of the equation. Not all disputes end up in litigation; understanding the forces that may affect litigant demand for trials ultimately will help us to explain state differences in litigation rates. There are notable state-to-state differences as well as intra-state changes in the fundamental structures of judicial systems that we believe can play a decisive role in shaping the willingness of potential litigants to take their cases to trial. Priest and Klein (1984) make this point with their selection hypothesis, which predicts that litigation is higher when uncertainty about judicial outcomes is higher. If there is relative certainty about the likely outcome of a legal dispute (i.e. having a strong a priori expectation about a likely outcome), litigants find it more profitable to resolve their dispute out of court, thereby avoiding court costs. From this perspective, it is when judicial decision-making is less predictable, or more uncertain, that disputants persist and take their cases to court.

What affects uncertainty? Hanssen (1999) provides a thoughtful clarification. Imagine a continuum of possible disputes that are distributed along a line running from right to left. In the middle of this continuum lies the decision standard (D) of the court. Plaintiffs win all decisions to the left and defendants win all cases to the right. Plaintiffs and defendants do not know what the outcome of their case would be but try to formulate an estimate of $\mathrm{D}$ based on their prior beliefs about its distribution.

They each formulate estimates that contain D as well as some error. A critical determinant of litigation is the error surrounding each party's estimates of D. As the variance in the estimates shrink, plaintiff and defendant will be inclined to agree on the likely outcome and will be disinclined to litigate. 


\section{Judicial Selection Structures}

Using the Priest and Klein logic, Hanssen (1999) presents a clever analysis of variation in state high court and trial court litigation rates. Hanssen reasons that elected judges are more predictable than their appointed counterparts; his theory thus turns on the expected trade-off between (1) judicial accountability to the electorate and politically power groups associated with judicial elections (i.e. "dependent judges"), and (2) the judicial autonomy that presumably emanates from the appointment of "independent judges," (Landes and Posner 1975). Hanssen then argues that, "If the institutions that promote judicial independence increase uncertainty, more litigation should be found where judges are appointed," $(1999,232)$. This is because potential litigants recognize the political forces that influence the range of decisions made by electorally-dependent judges, while appointed, presumably independent, judges can make a wider range of choices in a given case, resulting in outcomes that are less certain. However, Hanssen is careful to note that there is a countervailing consideration. The nomination of judges to the bench often leads to them serving for longer periods than their elected counterparts. This means that there is a continually increasing amount of information on their judicial propensities as they hand down rulings over a longer span of time; consequently their decisions become more predictable (206). Therefore, the difficulty lies in discerning which mechanism leads directly to more uncertainty and indirectly, to more litigation.

To test the effects of uncertainty on litigation rates, Hanssen examines appeal rates in state high court utility regulation cases, overall state high court litigation rates, and civil filing rates in state trial courts. His findings suggest that judicial independence has a net positive effect on judicial uncertainty and litigation rates in state high courts, with appointed justices having 40 percent more utility regulation cases and 10 percent more cases generally than elected justices. However, he found no significant difference between elected and appointed judges in trial courts where most tort litigation occurs. Thus, there is some reason to believe that electing judges reduces the supply of tort litigation because it reduces uncertainty about judicial preferences and the likely outcome of a case but at present the empirical findings are mixed. 


\section{State Citizen Ideology}

There are reasons to believe that the effects of elections on litigation rates should be conditional, rather than unconditional. For example, past research by Brace and Hall (e.g. 1997) illustrates a policyconditioning interaction between judicial selection systems and state citizen ideology. They find that state supreme court justices in elected states decide cases in a manner consistent with rational anticipation of voters' reactions to their rulings. In the case of tort litigation, advocacy of tort reform and the rhetoric of the litigation crises are key components of the Republican Party platform. Essentially, conservatives support free-market capitalism and business interests, and typically consider tort remedies as an illegitimate means of addressing conflict and loss. Litigation of disputes in conservative climates carries a stigma because such remedies are deemed to be unjustified entitlements or redistributions of wealth created by the overreaching of an activist judiciary. Alternatively, judges in more liberal states should be more inclined to support plaintiffs. Accordingly, we would expect that plaintiffs in liberal environments would be more inclined to pursue their cases in court than those in more conservative states, other things being equal. Therefore, elections are expected to connect judicial behavior (if not preferences) to the electorate (Brace and Hall, e.g. 1997). Thus, while electing judges should have the general effect of lowering litigation due to increased certainty of outcomes, we hypothesize that this effect is conditioned by the ideology of the citizenry that elects the judges. We would thus expect marginally more tort cases where the citizenry is liberal than where it is conservative.

\section{Judicial Professionalization Structures}

Our study is motivated by the Priest and Klein logic on outcome certainty and by Hanssen's application of that logic to judicial selection systems. However, we extend this general theory of judicial structural influence to consider how the professionalization of court structures may affect plaintiff willingness to pursue their cases to litigation. Judicial system salaries, court staffing, and size of dockets vary significantly from state to state. Courts scoring low on professionalization measures typically have overcrowded dockets, are understaffed, and are presided over by lower paid and presumably less skilled judges. For a plaintiff, cases under such circumstances raise the specter of prolonged and expensive 
litigation, with the prospects for victory rendered more ambiguous given the operating characteristics of these less professionalized courts. In contrast, plaintiffs in professionalized courts face less crowded dockets in courts administered more professionally and presided over by higher paid and presumably more skilled judges.

While it is common for studies of state court systems to include at least a cursory examination of institutional features, the characteristic of court professionalization has not been as widely used to predict state judicial outcomes or to address the issue of American litigiousness. The absence of professionalization as a conditioning influence of court behavior is especially interesting considering that professionalization is a critical element in studies of other state political institutions, most notably state legislatures. Numerous studies of state policy outcomes have demonstrated that professionalized legislatures produce social welfare and regulatory policies that are more favorable to less advantaged citizens (Mooney 1995; Squire 1992; Kearney and Sinha 1988; Berry 1979; Kagan, et al. 1977; Carmines 1974; Sharkansky and Hofferbert 1969). Judicial studies by Brace and Hall (2001) and Hero (1998) confirm that professionalization has a similar impact on state judicial institutions; these studies demonstrate that the professionalization of state supreme courts is just as important as judicial ideology and litigant characteristics in establishing the legal system as a redistributive agent of state government. ${ }^{1}$

Professionalization changes the fundamental structure of the courts as an institution; these institutional changes subsequently produce two significant shifts in judicial behavior. First, professionalization indirectly reduces the probability that judges will commit reversible error by increasing the amount of time and resources available for deliberation. Professionalized court systems place heavy emphasis on increasing the amount of time that judges dedicate to service, enhancing the availability and quality of resources provided to those jurists, and formalizing the organizational

\footnotetext{
1 Other scholars who forward "supply-side" theories of litigation rates argue that professionalized state courts have become the central political institution for redistributive policymaking, supplying the prime avenue for redressing grievances of distributive politics. In addition to Brace and Hall (2001), see Galanter (1988) and Bowman and Kearney (1988), who argue that "haves" heavily focus their lobbying efforts on professional state legislatures in an attempt to win favorable deregulation policies, forcing "have-nots" to seek political favor via litigation in the state courts (Sharkansky \& Hofferbert 1969; Berry 1979). The result is an overall increase in litigation rates.
} 
procedures that govern the institution's decision making processes (Mooney 1995; Squire 1993; Bowman \& Kearney 1988; Sharkansky \& Hofferbert 1969). Indeed, more professionalized court systems garner a greater percentage of state expenditures for their operating budgets and enjoy a larger number of staff members and professional court administrators than non-professionalized institutions. This lowers the costs of information for judges, allowing them to gather and review more case information in less time (Abel 1974; Canon \& Baum 1981; Brace \& Hall 2001). Professionalized court systems also provide judges with substantially higher salaries, which arguably attract better-qualified jurists who enter public service with a preference for value-neutral legalism and bureaucratized legal structures (Squire 1992; Morehouse \& Jewell 1993; Fiorina 1994). As a result, judges in more professionalized courts enjoy a deliberative environment that provides them with the tools needed to make fully informed, legally astute decisions. With a decreased possibility of winning on appeal, and without the advantage of harried judges who might not be able to consider all of the facts, litigants can be more certain of timely and authoritative judicial decisions, reducing the specter of endless and open-ended litigation. Defendants in tort cases should subsequently be encouraged to avoid court costs and pursue pre-trial settlement. For plaintiffs, however, the prospect of a quicker and more definitive outcome should increase the demand for court settlement if there is reason to expect a sympathetic outcome.

Career longevity and the resulting increases in the predictability of judicial decisions is the second shift in judicial behavior attributed to professional court systems. The higher salaries and benefits offered by more professional court systems serve to increase not only recruitment, but also retention of highly proficient judges (Brace and Hall 2001; Berry 1979). Additionally, judges in professionalized court systems feel less political pressure from outside interests, which may eliminate the desire of some judges to exit a highly stressful and politically demanding job (Squire 1993; Abel 1974). As judges remain on the bench for longer periods of time, potential litigants are better able to use past decisions to predict future risks of appearing before a particular jurist. This increase in judicial predictability, coupled with the aforementioned decrease in judicial error, serve to further strengthen certainty about judicial 
outcomes. For defendants, this should increase the likelihood of pre-trial settlement; however, for plaintiffs this could encourage greater determination to follow their case through to trial.

Most fundamentally, we believe that the institutional characteristics of more-professionalized court systems change judicial behavior in ways that ultimately result in altered expectations about the fruits of litigation. Because more professional court systems have the hallmarks of bureaucratization (e.g., specialization, division of labor, universal norms, professional training), they appear to be politically neutral institutions that are open to a larger variety of political interests (Hero 1998; Galanter 1985; Abel 1974; Carmines 1974). Such institutions are also typically subjected to more publicity and scrutiny than less professional institutions. This type of attention serves to enhance the quality of representation and responsiveness to the democratic demands; citizens recognize this responsiveness as an opportunity to access the courts (Squire 1993). The structural characteristics of professionalized judiciaries further lower the costs of access to the court system. With a broader professional resource base, including a larger number of staff members and legal administrators, judges have time to consider cases more carefully. Additionally, governing institutions with more formal structures and standard operating procedures have the capacity to accommodate a larger caseload (Abel 1974). More citizens are able to access the courts because many of the obstacles to getting into court are reduced and there is a more realistic expectation of a speedy conclusion to any potential litigation.

Although professionalization has the potential to make the courts more attractive avenues of political participation, a subsequent increase in litigation is not a foregone conclusion. A plaintiff may have an easier time getting on the docket and have the expectation that their case will proceed rapidly to an authoritative conclusion, but he should be reluctant to do so in a conservative state; easier access and expedited treatment should not encourage filings if the outcome is expected to be adverse. Plaintiffs, defendants, and their lawyers are also attuned to the political and ideological environment of a state. Citizen ideology has been shown to directly impact political institutions; liberal public opinion has a significant positive impact on state government policy outputs (Erikson, et al. 1993). Thus liberal (or 
conservative) public opinion is likely to correspond to an acceptance (or rejection) of tort litigation as a viable pathway to access the political system.

Professionalization should only make litigation more attractive for those potential litigants who reasonably believe that the prevailing ideological climate of the state will produce an outcome in their favor. And citizens do have reason to believe that more professional courts will be sympathetic to grievances about distributive politics. Brace and Hall (2001) and Berry (1979) demonstrated that operating resources and increased autonomy in recruitment and retention decisions have a significant impact on the likelihood that the interests of "have-nots" will be successfully represented in policy adoption. Additionally, professionalized court systems may attract more liberal (i.e., Democratic) judges who are more likely to make decisions favorable to "have-nots," (Berry 1979; Carmines 1974;

Sharkansky \& Hofferbert 1969). If more liberal judges are in fact attracted to professionalized judiciaries, lawyers for less advantaged litigants may be less likely to accept pre-trial settlement and more likely to take their chances in court, expecting more liberal judges to "improve society" by taking corporate interests to task. This echoes Galanter's (1985) assertions about the frequency of pre-trial settlement and the subsequent increases and/or decreases in litigation rates.

In sum, professionalization alters the judicial institution in a way that increases the certainties of beliefs about judicial behavior, thus producing an overall decrease in litigation as potential litigants forgo the costly process of achieving a safely predictable outcome, other things being equal. However, in states with a dominant liberal ideology, "have-not" litigants will interpret the characteristics of a professionalized judiciary as an invitation to access the political system in anticipation of a comparatively speedy, authoritative, and favorable outcome.

We wish to test these hypotheses about the interactive effects of professionalism and citizen ideology and election of judges and ideology against alternative hypotheses concerning the other characteristics of states that may affect the supply of cases. Our belief is that features of judicial institutions and the interactions of institutional characteristics with citizen preferences function to alter the selection processes of potential litigants. Where institutional features encourage expectations of access 
and victory by plaintiffs, or where they increase uncertainty about outcomes, tort cases will be more plentiful. Where these features lower plaintiffs' expectations of victory, or increase certainty about likely outcomes, they will reduce the number of court cases. In the end our model explores how citizen ideological preferences and institutional characteristics operate to shape the decision environment of potential litigants.

\section{Data, Model Specification, and Results}

Scholars generally agree that litigation rates are determined by a complex combination of political, economic, and social factors (Daniels 1982; McIntosh 1990; Harrington and Ward 1995; Posner 1997). The choice to file a lawsuit is the most basic indication of a citizen's willingness to seek conflict and dispute resolution via the judiciary rather than another state political institution or alternative mechanism. Our dependent variable is therefore a measure of the propensity of a state's citizens to assert themselves through the court system; we operationalize this concept as the number of tort cases filed in lower state courts per 100,000 citizens in a year. In aggregate, the more suits filed per person in a state, the greater the propensity of that state citizens to sue. Our tort case data were derived from information collected by the National Center for State Courts (NCSC) (1995). As previously outlined, our primary independent variables are state Court Professionalism, Selection Method, and Citizen Ideology (see Variable Description Index for explanation of variable measurement).

To test our hypotheses, we use pooled cross-sectional, time-series analysis. Due to the relative difficulty in obtaining state tort litigation data and our desire to analyze litigation rates over time, we have a relatively small sample, both across states $(\mathrm{N}=10)$ and time $(\mathrm{N}=20)$. While inclusion of a greater number of states would increase the generalizability of our results, data from all but the most recent years is limited. Given our interest in explaining temporal variation in litigation, we chose states on which appropriate data were collected for 20 years. The NCSC has data for 16 states over this time period, but six of these deviated over time in their data collection methodology, which precluded their use. The states in our sample are Colorado, Kansas, Florida, Maryland, Tennessee, Texas, Washington, Maine, 
Hawaii, and North Dakota. Although these states constitute a comparatively small number of cases, they do represent a good cross-section of all regions and political cultures, and include states with large and small populations.

In building our model of state tort litigiousness, we draw on the previously described literature on civil litigation rates which have focused primarily on social development and political culture explanations for litigation activity. We have adopted and expanded these general theoretical perspectives by identifying three broad categories of influences on litigation rates: social and economic environment, political structure and policy, and legal structures and environment.

\section{Social and Economic Environment}

Social development theory suggests that states with high population density, high poverty rates, significant levels of income inequality, and relatively urbanized and industrial populations are more likely to experience increases in tort filings (Yates, et al. 2001; Harrington \& Ward 1995). The increase in litigation rates may be attributed to two factors. First, a higher degree of social complexity increases the likelihood that potential disputes and litigation events will occur (Daniels 1982; Sarat \& Grossman 1975), thus increasing the need for dispute resolution. Second, informal methods of dispute resolution are less likely to suffice in socially complex environments, where individuals are less likely to share regular social interactions (McIntosh 1990; Daniels 1982). In short, strangers are more likely to go to court with one another than are those with ongoing social interaction and close-knit community bonds. As a consequence, legal systems in socially complex states provide the cheapest avenue of access to formal political processes (Glick 2004; Yates, et al. 2001; Atkins \& Glick 1976). The more complex a society, the greater the need for the formal dispute resolution process of the courts. We use the percentage of the state's population living in a standard metropolitan statistical area (SMSA) to measure social complexity. We hypothesize that this variable will be positively related to rates of tort litigation.

We also wish to control for the variation in potential litigation events that may accompany social complexity and thus influence the rate of tort litigation in a state. We include in our model the number of automobile accidents involving injury or death in a state (per 100,000 citizens). While this variable does 
not capture all potential litigation events, it does account for a primary source of tort lawsuits (Schmidt, Browne, and Lee 1997).

Civil justice system critics often frame the tort crisis issue as one in which self-serving litigants seek unwarranted compensation against the common public good (Galanter 1983). One option for potential litigants who have suffered costs due to others' negligence is to internalize these costs, that is, to "lump it" (Galanter 1996). This is a more costly choice for those who are already economically disadvantaged; such citizens have less of an ability to recover from financially-damaging events (Schmidt, Browne, and Lee 1997). However, the contingency fee system in tort litigation, in which the plaintiff only pays for representation if he or she wins the suit, lowers the costs for impoverished citizens who choose to bring tort suits. Galanter posits an even broader explanation for why impoverished "have nots" might prefer the court system to more conventional means of advancing their self interest:

The various kinds of "have nots" ... have fewer resources to accomplish changes through legislation or administrative policy-making. The advantages of the organized, professional, wealthy and attentive in these forums is well known. Litigation, on the other hand, has the flavor of equality. ... Thus, litigation is a particularly tempting arena to "have nots"(Galanter 1974, 135).

Therefore, we hypothesize that states with more "have nots" will tend to experience higher levels of tort litigation. We measure this determinant as the percent of a state's population living below the poverty level. Finally, we follow Judge Posner's (1997) theoretical lead and hypothesize that states with college graduates (per capita) will have increased litigation. Posner reasons that college educated citizens should be more keenly aware of their legal rights and opportunities for redress and that they may be more comfortable dealing with legal professionals and the processes of government.

\section{Political Culture, Structure, and Policy}

A wide range of studies has substantiated the theory that states have their own political cultures which impact the development of state political institutions and the nature of policy outputs (Grossman et al., 1982; Gray 1973; Walker 1969). As noted previously, one of our primary explanations for citizen legal mobilization, citizen ideology, has been shown to directly impact political institutions; liberal public opinion has a significant positive impact on state policy outputs (Erikson, et al. 1993). Indeed, many 
studies have found an empirical relationship between various political phenomena and a state electorate's ideology, as measured on a liberal-conservative scale (e.g. Berry, et al. 1998; Erikson, Wright, McIver 1993). In addition to ideology, the degree to which state political institutions are open to diverse and competing interests may impact how citizens choose to participate in the political system. For instance, interparty competition- -the degree to which partisan parity exists in a state's government and electorate- has been linked to more responsive government and to policies that are more generous to the poor (Key 1949; Holbrook and Van Dunk 1993). Interparty competition also increases access to government actors to resolve grievances, which may decrease the use of courts as alternative forums for conflict resolution. However, a rival hypothesis is that interparty competition creates a larger number of political losers and potential litigants if one party captures most political offices (McIntosh 1983). But since interparty competition produces in-party replacement over time, we expect greater party competition has an overall dampening effect on litigiousness. We measure interparty competition with the district-level measure constructed by Holbrook and Van Dunk (1993), and updated by Smith (1997).

Finally, the nature of an institution's public policy outputs may alter the rates at which citizens seek to access various institutions of state government. Thus, state court systems may experience redistributive mobilization tactics by their clientele population (litigants) when other branches of state government choose to provide relatively less generous social assistance programs to them (Galanter 1983; Pfennigstorf and Gifford 1991). We hypothesize that states with a more charitable social safety net will experience lower rates of tort litigation. We include the maximum Aid to Families with Dependent Children (AFDC) payment for a family of four (adjusted with the consumer price index) in our model to measure state social welfare generosity. To control for the impact of judicial "policy outputs" - that is, the generosity of verdicts issued in tort cases - we include a measure indicating the number of milliondollar verdicts reached per 100,000 state citizens. We expect that the appearance of generous verdicts will lead to public perception that the court system is willing to redistributive greater amounts of wealth, thus increasing the propensity of citizens to sue. 


\section{Legal Structure and Environment}

Dissatisfaction with the traditional tort liability system has led some states to adopt "no-fault" systems to compensate victims of malfeasance. Such systems provide for first-party insurance benefits to be paid regardless of the fault of the respective parties. Importantly, rather stringent restrictions on the rights of injured parties to sue are included in these no-fault systems. Such restrictions typically involve only allowing suits when damages exceed a defined dollar value and when cases involve serious losses, such as death or dismemberment (Gastel 2000; Schmidt, Brown, and Lee 1997). In adopting a no-fault system, a state provides an alternative method of handling malfeasance compensation, while greatly limiting the availability of traditional legal redress. Therefore, we hypothesize that the existence of a nofault system will reduce the rate of tort litigation filings. Five of the ten states in this study have no-fault systems over varying time frames. We code this variable as one if a no-fault system is in place, and zero otherwise.

Tort reforms are legal modifications of traditional or existing tort doctrine, typically geared toward reducing the number of tort claims and lowering verdict amounts. Over the past few decades, state legislatures have enacted a number of such reforms, in large part as a response to business and insurance groups' claims of a litigation crisis (Schmidt, Browne, and Lee 1997). We assess the five most common forms of state tort reform (Schmidt, Browne, and Lee 1997): caps on non-economic damages, caps on punitive damages, limits on joint and several liability, modifications of the collateral source rule, and sanctions on frivolous actions. These reforms, and the construction of the index, are described in the Appendix. The tort reform index ranges from zero (no reforms) to five (all reforms in place). We also analyzed the data for litigation surges from litigants attempting to beat the effective date of tort reform legislation. We found only one instance of such behavior (in Washington State in 1986) and adjusted our model specification with a dummy variable to control for this instance.

Critics of the American civil justice system often argue that an overabundance of attorneys drives up tort litigation rates (Galanter 1993). The assumption is that attorneys enable and encourage potential litigants to bring tort cases. Galanter (1993) challenges the notion that there is an overabundance of 
attorneys in the United States and notes that, compared with other countries, the number of attorneys per capita in the United States approximates this country's proportion of the world's gross national product. We test the hypothesis that states with more attorneys per capita have higher tort litigation rates by including a measure of this variable in our model.

Finally, a number of our independent variables, when possible and appropriate, are lagged to allow time for their influence on state tort litigation rates to become apparent. Because the scholarly literature does not provide guidance on the appropriate lag structures, we use a one-year lag for all of these explanatory variables.

\section{Results}

In Table 1 we display the results of our analyses, including estimates for a basic additive model and the interactive model that we have proposed, which considers the two institutional structural characteristics, court professionalism and judicial selection method, in tandem with the liberalism of the state citizenry. The effect on tort litigation rates of changes in the independent variables (minimum to maximum observed values) is presented in the final column of the table ("net effects"). Both models yield excellent explanatory power with the latter, interactive model, providing slightly more. In the additive model we find that the control variable for Washington state's citizens' rush to file cases in 1986 to beat a tort reform deadline is statistically significant as is the indicator variable for no-fault compensation states. Interparty competition, the percent of college graduates in a state, and states' per capita million dollar verdicts also emerge as viable explanations for citizen legal mobilization. ${ }^{2}$ Finally, as hypothesized, state court professionalism has a positive and statistically significant relationship to litigation rates. This relationship is more fully developed in our interactive model. In this model, we find that both interactive terms (Court Professionalism * Liberalism and Elected Judges * Liberalism) are statistically significant and positively related to state litigation rates. The component terms of the interactions are also statistically significant, but, given that they are negatively related to tort litigation, it is important to explain the highly

2 We actually use the coefficients for the interactive model to estimate the net effects shown in Table 1 for all statistically significant independent variables. For million dollar verdicts we use the coefficient from the additive model to estimate net effects since it does not quite attain statistical significance in the interactive specification. 
conditional nature of these findings. As Freidrich (1982) notes in his seminal treatment on interpreting interactions, the coefficients (and standard errors) for the component terms of an interaction denote the respective values for said component term when the other related component term is at a specific value, namely zero. Thus, the coefficients and standard errors for our component terms are highly conditional, and, in some instances, are based upon the other component term's values being at levels that, while theoretically possible, are not actually observed in the data set. This phenomenon can sometimes make the statistical results for interactive relationships rather non-intuitive or accessible for substantive interpretation. However, recent work by Brambor, Clark, and Golder (2005) provides valuable practical insight for analyzing the conditional nature of such relationships. Essentially, the relationship between the dependent variable, $\mathrm{Y}$, and the component term of interest, $\mathrm{X}$, is conditioned upon the level of the other component term of the interaction, $\mathrm{Z}$ - the modifying variable. Thus, both the coefficient and the standard error associated with the relationship between $\mathrm{Y}$ and $\mathrm{X}$ may change at different levels of $\mathrm{Z}$. This conditional relationship is perhaps best expressed graphically. Figure 1 displays the marginal effect of Court Professionalism (X) on tort litigation (Y) at varying levels of state citizen Liberalism (Z) - the modifying variable. A similar graphical display is provided in Figure 2 for the component terms Judicial Selection (X) and Liberalism (Z). The solid sloping line suggests the marginal effects of $\mathrm{X}$ as $\mathrm{Z}$ is increased. As Brambor, et al. explain, the $95 \%$ confidence intervals around the solid sloping line allow us to determine the conditions under which Court Professionalism (X in Figure1) and Judicial Selection (X in Figure 2) have a statistically significant effect on the level of tort litigation rates - they have a statistically significant effect whenever the upper and lower bounds of the confidence interval are both above (or below) the solid zero line. ${ }^{3}$

\footnotetext{
${ }^{3}$ It is important to note that we display a range of Erikson, Wright and McIver's state liberalism scores from 0-30 in these figures, while, in our data set, these scores range from approximately 17 to 29 . Therefore, it is important to focus on this range of liberalism in assessing our conditional relationships. However, this limitation hardly renders our results unsubstantial. For instance, in both Figures 1 and 2 the effect becomes statistically significant at a liberalism score of about 23. Approximately one-fourth of the state-year observations in our data set are higher than this value. Furthermore, while we make no claims as to other states given the limits of our ten state litigation data, Erikson, et al.'s scores for state liberalism do encompass state-years that fall within the full 0-30 range, and in fact, go much higher.
} 
In Figure 1 we can see that if citizen liberalism is very low (i.e. a very conservative environment), then Court Professionalism is negatively associate with litigation. This is as it should be, conservativeprofessional (certain) environments provide very clear implications for potential plaintiffs - you will not win, so settle. Conversely, in very liberal (certain) environments Court Professionalism is associated with increased litigation. Figure 2 suggests a similar situation regarding Judicial Selection. Elected judges are associated with decreased litigation in conservative environments and increased litigation in liberal environments. In Figure 3 we provide even more insight on these conditional relationships by evaluating the interactive relationship of Court Professionalism and Liberalism on tort litigation rates in elected and non-elected environments, separately. ${ }^{4}$ This figure suggests that the interactive relationship holds as statistically significant in both selection contexts, but works at differing levels of liberalism in each situation (at low levels in the elected context and at higher levels in the appointed context). In sum, these figures suggest exactly the type of conditional relationship between state court institutional structures and citizen ideology that we proposed.

\section{Conclusion}

The results presented above conform to our general expectation that tort litigation rates are shaped by socio-legal forces influencing the supply of potential cases on one hand, and by structural characteristics of courts and the distribution of ideological preferences within the states that shape litigant strategies concerning pre-trial or court resolution of disputes. Our primary interest was in the latter influences and it is here that we find what we believe are our most notable findings. Specifically, litigation rates appear sensitive to the conditioning influences of how judges are selected, how courts are administered, and the relative liberalism or conservatism of state citizens. All of these influences were statistically significant as were multiplicative interaction terms containing each of these influences.

\footnotetext{
4 This figure emanates from a triple interactive model suggested by Brambor, et al. (2005). The results of the rest of this triple interaction model are substantially similar to our main interactive model.
} 
The implications of these results help provide a more integrated view of the effects of court structure on variations in tort litigation than has been presented previously. Quite clearly, electing judges reduces tort litigation and this conforms to the Priest and Klein (1984) selection hypothesis. This, however, is only part of the story, albeit an important one. Notably, among the states that elect their judges there are significantly more tort cases where the citizenry is more liberal than when it is more conservative indicating that plaintiffs may be more tenacious about getting their cases into court in more liberal states when there is a higher expectation of winning. Alternatively, this suggests as well that plaintiffs are more reluctant to pursue their cases in conservative states where there is less cause for optimism about a court outcome. These results thus conform to the general hypothesis that elections effect certainty that in turn influences litigation rates. They go beyond this, however, to also illustrate how the variations in the direction of that certainty regarding winning and losing for plaintiffs further shapes litigation rates.

We further reasoned that variations in court professionalization should influence the degree of certainty potential litigants had about an outcome in court with certainty varying positively as a function of court professionalization. Our results support this conclusion: litigation rates were significantly lower in more professionalized states, ceteris paribus. However, we also find that the effects of professionalization are significantly conditioned by differences in state ideologies. Stated simply, a litigant confronting a professionalized court system in a liberal state would be much more likely to pursue their case in court than a litigant facing a similarly professionalized court system in a conservative state.

The composite influence of these three influences was revealed most starkly in Figure 3. This figure contrasts the composite effects for professionalization and state ideology for elected versus nonelected states. Very clearly, litigation rates in elected states are highly sensitive to the joint values of liberalism and professionalization. The effects of electing judges on tort litigation rates among the states are highly conditioned by the joint values taken by citizen ideology and court professionalization. The lowest levels of litigation were observed in conservative states with elective judges and low levels of court professionalization. Presumably, these are states where plaintiffs would have the lowest expectation 
of prevailing on court. More cases were observed as values of professionalism and liberalism increase in states that elect their judges. This too would conform to the notion that more cases are observed as plaintiffs' chances of victory increase. Finally, the most cases were observed in states that did not elect their judges. The conditional effects of ideology and professionalization are still evident but substantially less pronounced than in states that elect their judges as indicated by the more modest slope depicted in Figure 3. Consistent with the selection hypothesis, greater uncertainty about likely outcomes when judges are not elected would seem to foster more litigation. However, the modest but significant conditioning effects of citizen liberalism and court professionalization would suggest that when plaintiffs have a higher expectation of winning, litigation rates increase, just as was the case for states with elected judges.

The striking difference of the effects of professionalization and ideology between states with elective and non-elective judges may also reveal something about the relative independence of judges selected by the two methods. Litigation rates in states with elected judges are highly sensitive to levels of court professionalization and citizen liberalism or conservatism. It appears that a little information about the level of court professionalization and citizen ideology can go a long way in shaping whether litigants will proceed to court in these states. Alternatively, this same information elicits much less variation in litigation in states with appointed judges, presumably because these judges are more autonomous. Knowing that the citizenry is liberal and that the courts are professionalized does much less to influence litigation when judges are appointed and presumably are more unpredictable.

In light of our findings we believe it is important to take a somewhat more nuanced view of variations in tort rates across the U.S. Tort rates are partly shaped by societal factors that shape the supply of potential disputes. Beyond this, forces operate to shape the expectations potential litigants form about the prospects for victory in court. Our results suggest that this expectation is shaped by how judges are selected but, more importantly, by the institutional and political contexts in which judges operate. The interplay of the relative latitude for judicial discretion within a matrix of court professionalization and citizen ideology form the basis upon which litigants decide to pursue their cases in court. 


\section{References}

Abel, Richard L. (1974). "A Comparative Theory of Dispute Institutions in Society." Law and Society Review 8(2): 217-347.

Adler, Freda, and William S. Laufer (1995).. The Legacy of Anomie Theory. New Brunswick, NJ: Transaction Publishers.

Atkins, Burton M. and Henry Glick (1976). "Environmental and Structural Variables as Determinants of Issues in State Courts of Last Resort." American Journal of Political Science 20(1): 97-115.

Berry, William D. (1979). "Utility Regulation in the States: The Policy Effects of Professionalism and Salience to the Consumer." American Journal of Political Science 23(2): 263-277.

Berry, William D., Evan J. Ringquist, Richard C. Fording, and Russell L. Hanson (1998). "Measuring Citizen and Government Ideology in the American States, 1960-93." American Journal of Political Science 42:327-48.

Bowman, Anne, and Richard Kearney (1988). "Dimensions of State Government Capability." Western Political Quarterly 41(2): 341-362.

Brace, Paul and Melinda Gann Hall (2001). “'Haves' Versus 'Have Nots' in State Supreme Courts: Allocating Docket Space and Wins in Power Asymmetric Cases." Law and Society Review 35(2): 393-417.

Brace, Paul and Melinda Gann Hall (1995). "Studying Courts Comparatively: The View from the American States." Political Research Quarterly 48(1): 5-29.

Brace, Paul, and Melinda Gann Hall (1997). "The Interplay of Preferences, Case Facts, Context, and Rules in the Politics of Judicial Choice.” The Journal of Politics 59(4): 1206-1231.

Brambor, Thomas, William Clark, and Matt Golder. (2005). "Understanding Interaction Models: Improving Empirical Analyses." Political Analysis 13: 1-20.

“Chief Justice Urges Greater Use of Arbitration,” N.Y. Times, Aug. 22, 1985, at A21

Caldeira, Gregory A. (1983). "On the Reputation of State Supreme Courts." Political Behavior 5(1): 83-108.

Canon, Bradley C. and Lawrence Baum (1981). "Patterns of Adoption of Tort Law Innovations: An Application of Diffusion Theory to Judicial Doctrines." The American Political Science Review 75(4): 975-987.

Carmines, Edward G. (1974). "The Mediating Influence of State Legislatures on the Linkage Between Interparty Competition and Welfare Policies." The American Political Science Review 68(3): 1118-1124. 
Daniels, Stephen (1982). “Civil Litigation in Illinois Trial Courts.” Law \& Policy Quarterly 4: 190-214

Erikson, Robert S., Gerald C. Wright, Jr., and John McIver (1993). Statehouse Democracy. New York: Cambridge University Press

Fiorina, Morris (1994). "Divided Government in the American States: A Byproduct of Legislative Professionalism?” The American Political Science Review 88(2): 304-316.

Freidrich, Robert. (1982). "In Defense of Interaction Terms In Multiple Regression Equations." American Journal of Political Science 26: 797-833.

Galanter, Marc (1974). "Why the 'Haves' Come Out Ahead: Speculations on the Limits of Legal Change." Law and Society Review 9: 95-160.

Galanter, Marc (1975). “Afterword, Explaining Litigation.” Law and Society Review 9: 347-368.

Galanter, Marc (1985). "The Legal Malaise; or, Justice Observed." Law and Society Review 19(4): 537-556.

Galanter, Marc (1986). “The Day After the Litigation Explosion.” Maryland Law Review 45:3-39.

Galanter, Marc. (1993). "News From Nowhere: The Debased Debate on Civil Justice.” Denver University Law Review 71:77-113.

Galanter, Marc. (1996). "Real World Torts: An Antidote to Anecdote." Maryland Law Review 55: 1093160.

Galanter, Marc (2002). "The Turn Against Law: The Recoil Against Expanding Accountability.” Texas Law Review 285: 285-87.

Gasaway, Robert. (2001). "The Problem of Tort Reform: Federalism and the Regulation of Lawyers." Harvard Journal of Law \& Public Policy 25:953-63.

Gastel, Ruth. (2000). I.I.I. Insurance Fact Book 2000. New York: Insurance Information Institute.

Glick, Henry (2004). "Courts: Politics and the Judicial Process." Politics in the American States ( $8^{\text {th }}$ edition). Eds. Virginia Gray and Russell Hanson. Washington DC: CQ Press: 232260.

Gray, Virginia (1973). "Innovation in the States: A Diffusion Study.” The American Political Science Review 67:1174-1185.

Grossman, Joel, Herbert Kritzer, Kristin Bumiller, Austin Sarat, and Stephen McDougal (1982). "Dimensions of Institutional Participation: Who Uses the Courts, and How?" The Journal of Politics 44(1): 86-114.

Grossman, Joel, and Austin Sarat (1975). "Litigation in the Federal Courts: A Comparative Perspective." Law and Society Review 9:321-46

Haltom, William and Michael McCann (2004). Distorting the Law: Politics, Media, and the Litigation Crises. Chicago: University of Chicago Press. 
Hamm, Keith and Gary Moncrief (2004). "Legislative Politics in the States." Politics in the American States ( $8^{\text {th }}$ edition). Eds. Virginia Gray and Russell Hanson. Washington DC: CQ Press: 157-193.

Hanssen, F. Andrew (1999). "The Effect of Judicial Institutions on Uncertainty and the Rate of Litigation: The Election versus Appointment of State Judges.” The Journal of Legal Studies 28(1): 205232

Harrington, Christine and Daniel Ward (1995). "Patterns of Appellate Litigation, 1945 - 1990." Contemplating Courts. Ed. Lee Epstein. Washington, DC: CQ Press.

Harris, Peter (1985). "Ecology and Culture in the Communication of Precedent among State Supreme Courts, 1870-1970.” Law \& Society Review 19(3): 449-486.

Hero, Rodney (1998). Faces of Inequality: Social Diversity in American Politics. New York: Oxford University Press.

Holbrook, Thomas M., and Emily Van Dunk (1993). "Electoral Competition in the American States." American Political Science Review 87:955-62.

Jacob, Herbert (1997). “The Governance of Trial Judges.” Law and Society Review 31(1): 3-30.

Kagan, Robert, Bobby Infelise, and Robert Detlefson (1977). "The Evolution of State Supreme Courts." 76 Michigan Law Review 961.

Kagan, Robert (2002). Adversarial Legalism: The American Way of Law. Cambridge: Harvard University Press.

Kearney, Richard, and Chandan Sinha (1988). "Professionalism and Bureaucratic Responsiveness.” Public Administration Review 48(1): 571-579.

Key, V.O. (1949). Southern Politics in State and Nation. New York: Alfred A. Knopf.

Landers, William M., and Richard A. Posner (1975). "The Private Enforcement of Law." The Journal of Legal Studies 4(1): 1-46.

Langer, Laura (1999). "Measuring Income Distribution Across Space and Time in the American States." Social Science Quarterly 80:55-67.

Marvell, Thomas B. (1994). "Tort Caseload Trends and the Impact of Tort Reforms.” Justice System Journal 17:193-206.

McIntosh, Wayne V. (1983). "Private Use of a Public Forum: A Long Range View of the Dispute Processing Role of Courts.” American Political Science Review 77:991-1010.

McIntosh, Wayne V. (1990). The Appeal of Civil Law. Urbana, IL: University of Illinois Press.

Merton, Robert K.(1968). Social Theory and Social Structure. New York: Free Press

Moffett, Kenneth (2002). "The Effects of Professionalization and Term Limits on the 
Composition of State Legislatures." Paper presented at the 2004 Meeting of the Western Political Science Association, Portland, OR.

Mooney, Christopher Z. (1995). "Citizens, Structures, and Sister States: Influences on State Legislative Professionalization.” Legislative Studies Quarterly 20(1): 47-67.

Morehouse, Sarah McCally and Malcolm E. Jewell (2003). State Politics, Parties, \& Policy. New York: Rowman \& Littlefield.

Munger, Frank. 1990. "Studying Litigation and Social Change." Law \& Society Review 24(2): 595-616.

National Center for State Courts (1976-95). State Court Caseload Statistics: Annual Report. Williamsburg, VA: National Center for State Courts.

National Center for State Courts (1995). Tort Filings in 16 States, 1975-95. Williamsburg, VA: National Center for State Courts.

National Center for State Courts (1995). Tort Caseloads in State Trial Courts of General Jurisdiction 1987-95. Williamsburg, VA: National Center for State Courts

Olson, Walter (1991). The Litigation Explosion: What Happened When America Unleashed the Lawsuit. Penguin USA.

Pfennigstorf, Werner, and Donald G. Gifford (1991). A Comparative Study of Liability Law and Compensation Schemes in Ten Countries and the United States. Oak Brook, IL: Insurance Research Council.

Posner, Richard. (1997). "Explaining the Variance in the Number of Tort Suits Across U.S. States and Between the United States and England." Journal of Legal Studies 26:477-89.

Priest, George, and Benjamin Klein (1984). "The Selection of Disputes for Litigation.” Journal of Legal Studies 13.1

Roper, Robert T. (1986). "The Propensity to Litigate in State Trial Courts, 1981-1984, 1984-1985." Justice System Journal 11:5-15.

Saks, Michael (1992). "Do We Really Know Anything About the Behavior of the Tort Litigation System - And Why Not?" University of Pennsylvania Law Review 140: 1147.

Sarat, Austin, and Joel B. Grossman (1975). "Courts and Conflict Resolution: Problems in the Mobilization of Adjudication.” The American Political Science Review 69:1200-1217.

Sarat, Austin (1985). "The Litigation Explosion, Access to Justice, and Court Reform: Examining the Critical Assumptions." Rutgers Law Review 37:319-320.

Schmidt, Joan, Mark Browne, and Han Duck Lee (1997). "The Effects of State Tort Reforms on Claim Filings." Risk Management and Insurance Review 1:1-17.

Sharkansky, Ira and Richard I. Hofferbert (1969). "Dimensions of State Politics, Economics, and Public Policy.” The American Political Science Review 63(3): 867-879. 
Sheehan, Reginad S., William Mishler, and Donald Songer (1992). "Ideology, Status, and the Differential Success of Direct Parties before the Supreme Court." American Political Science Review 86: 464-471.

Smith, Mark A. (1997). "The Nature of Party Governance: Connecting Conceptualization and Measurement." American Journal of Political Science 41:1042-56.

Squire, Peverill (1992). "Legislative Professionalization and Membership Diversity in State Legislatures.” Legislative Studies Quarterly 17: 69-79.

Squire, Peverill (1993). "Professionalization and Public Opinion of State Legislatures." The Journal of Politics 55(2): 479-491.

Stookey, John A. (1986). “Economic Cycles and Civil Litigation.” Justice System Journal 11:282-302.

Vines, Kenneth N. and Herbert Jacob (1971). "State Courts." Politics in the American States, $2^{\text {nd }}$ edition. Eds. Kenneth Vines and Herbert Jacob. Boston: Little, Brown: 272-311.

Vold, George B., and Thomas J. Bernard (1986). Theoretical Criminology. $3^{\text {rd }}$ ed. New York: Oxford University Press.

Walker, Jack L. (1969). The Diffusion of Innovations among the American States. The American Political Science Review 63 (3):880-899.

Wanner, Craig (1974). "The Public Ordering of Private Relations: Part One: Initiating Civil Cases in Urban Trial Courts." Law and Society Review 8: 421-440.

Yates, Jeff, Belinda Creel Davis, and Henry R. Glick (2001). "The Politics of Torts: Explaining Litigation Rates in the American States." State Politics and Policy Quarterly Summer: 127-143. 


\section{Variable Description Appendix}

Tort Filings: the number of tort cases filed per 100,000 residents. Source: National Center for State Courts (1995).

Income Inequality: a Gini index measure of income inequality compiled by Langer (1999). A score of zero indicates a perfectly equal distribution while a score of one indicates that all of the income of the state is concentrated in a single household. The variable is lagged one year.

Poverty: the percentage of people in a state living below the poverty line. Source: United States Department of Commerce (various years). The variable is lagged one year.

SMSA: the percent of people in a state living in Standard Metropolitan Statistical Areas. Values for unavailable years were interpolated. Source: United States Department of Commerce (various years). The variable is lagged on year.

Interparty Competition: a cross-sectional measure of party competition in a state based on legislative district competition. Larger scores indicate increased competition. Source: Holbrook and Van Dunk (1993), and updated by Smith (1997).

Social Safety Net: the maximum monthly AFDC benefit for a family of four, adjusted for inflation with the consumer price index. Lagged one year. Source: United States House of Representatives Committee on Ways and Means (various years). The variable is lagged one year.

Tort Reform: an index of the most common forms of state tort reform legislation:

Caps on Non-economic Damages - limits awards for nonspecific losses, such as pain and suffering and mental anguish.

Caps on punitive Damages - limits awards assessed for the purpose of punishing the defendant and vindicating the plaintiff.

Limitations on Joint and Several Liability - limits the ability of plaintiffs to sue each jointly liable defendant for the entire amount of damages suffered.

Modification of Collateral Source Rule - limits the ability of plaintiffs to collect from

collateral sources, such as health of disability insurers, in addition to damages assessed against defendants.

Sanctions on Frivolous Actions - imposes penalties when a litigants takes an action (e.g., brings a claim or uses a defenses) that lacks merit or is frivolous.

These reforms were first coded as dichotomous variables to indicate the presence of the reform in a given state in a given year. These dichotomous variables were then summed in order to form an index variable that denotes the number of reforms in a state for a given year. Source: Schmidt, Browne, and Lee (1997). The variable is lagged one year.

No-Fault: a dummy variable coded one if a state in a given year is under a no-fault compensation system and coded zero otherwise. A no-fault system exists when a state's laws provide for both the payment of no-fault first-party benefits and restrict the right to sue. Source: Gastel (2000). The variable is lagged one year.

Lawyers: the number of lawyers per 100,000 state residents. Source: Market Research Department of the American Bar Association (various years). The variable is lagged one year. 
Automobile Accidents: the number of motor vehicle accidents per 100,000 state residents. Source: United States Department of Transportation Federal Highway Administration (various years). The variable is lagged one year.

Washington State: a dummy variable coded 1 to control for tort activity in Washington State in the year 1986. This spike in litigation is due to efforts by litigants to file cases before the state's tort reform deadline.

Lower Court Professionalism: an index of professionalism for the state trial courts of general jurisdiction measure developed consistent with the method used by Brace and Hall (2001). Based on data on state judicial resources and from 1975, 1987, and 1993, with values for those years repeated for missing years.

Million-dollar Verdicts: the number of verdicts per 100,000 citizens awarding damages greater than or equal to one million dollars. The original measure was calculated as the total number of verdicts from 1962-1989, Agnew and Marshall (1990). Source: Current Award Trends, Jury Verdict Research, Inc. (1990).

Elected States: a dummy variable coded 1 if a state provides for the election of lower court judges and coded zero otherwise. Source: (year).

College Degree: the percentage of a state's citizens age 25 and older possessing a Bachelor's degree or higher. Source: United States Census Bureau (repeated values for census years).

State ideology: a measure of state ideological climate based on aggregate citizen public opinion and partisanship. Higher scores indicate a more liberal ideological climate. Source: Erikson, Wright, and McIver (1993), with updated scores (1976 - 2003) available for download from:

http://www.php.indiana.edu/ wright1. 
TABLE ONE: Regression Results for Tort Litigation and Net Effects

\begin{tabular}{|c|c|c|c|}
\hline Variables & Additive Model & Interactive Model & Net Effects $\dagger$ \\
\hline Washington 1986 & $\begin{array}{l}241.696 \\
(18.23)^{* *}\end{array}$ & $\begin{array}{l}239.106 \\
(17.36)^{* *}\end{array}$ & +239.1 \\
\hline No Fault $t-1$ & $\begin{array}{l}-54.025 \\
(4.68) * *\end{array}$ & $\begin{array}{l}-54.025 \\
(5.03)^{* *}\end{array}$ & -54.43 \\
\hline Auto Accidents t-1 & $\begin{array}{l}0.032 \\
(2.45)^{* *}\end{array}$ & $\begin{array}{l}0.040 \\
(3.08) * *\end{array}$ & +53.66 \\
\hline Lawyers $t-1$ & $\begin{array}{l}-0.007 \\
(1.03)\end{array}$ & $\begin{array}{l}-0.010 \\
(1.45)\end{array}$ & \\
\hline Million Dollar Verdicts & $\begin{array}{l}12.723 \\
(1.89)^{*}\end{array}$ & $\begin{array}{l}8.317 \\
(1.29)\end{array}$ & +68.65 \\
\hline Tort Reform Index $t-1$ & $\begin{array}{l}0.691 \\
(0.36)\end{array}$ & $\begin{array}{l}-0.752 \\
(0.40)\end{array}$ & \\
\hline AFDC Benefits $t-1$ & $\begin{array}{l}-0.100 \\
(0.87)\end{array}$ & $\begin{array}{l}-0.085 \\
(0.72)\end{array}$ & \\
\hline Interparty Competition & $\begin{array}{l}-1.566 \\
(4.95)^{* *}\end{array}$ & $\begin{array}{l}-1.291 \\
(4.10)^{* *}\end{array}$ & -78.63 \\
\hline Metropolitan Area t-1 & $\begin{array}{l}-0.142 \\
(0.52)\end{array}$ & $\begin{array}{l}0.144 \\
(0.51)\end{array}$ & \\
\hline College Graduates & $\begin{array}{l}2.367 \\
(2.99) * *\end{array}$ & $\begin{array}{l}2.326 \\
(3.11)^{* *}\end{array}$ & +44.62 \\
\hline Below Poverty Line $t-1$ & $\begin{array}{l}0.521 \\
(0.73)\end{array}$ & $\begin{array}{l}0.729 \\
(0.99)\end{array}$ & \\
\hline Court Professionalism & $\begin{array}{l}11.379 \\
(2.37)^{* *}\end{array}$ & $\begin{array}{l}-110.112 \\
(3.03)^{* * *}\end{array}$ & See Figures \\
\hline Citizen Liberalism & $\begin{array}{l}-2.142 \\
(1.24)\end{array}$ & $\begin{array}{l}-7.014 \\
(3.19)^{* *}\end{array}$ & See Figures \\
\hline Elected Judges & $\begin{array}{l}6.010 \\
(0.78)\end{array}$ & $\begin{array}{l}-163.805 \\
(2.50)^{* *}\end{array}$ & See Figures \\
\hline Court Professionalism * & & & \\
\hline Liberalism & & $\begin{array}{l}5.263 \\
(3.41)^{* *}\end{array}$ & See Figures \\
\hline Elected Judges * & & & \\
\hline Liberalism & & $\begin{array}{l}7.627 \\
(2.59)^{* *}\end{array}$ & See Figures \\
\hline Constant & $\begin{array}{l}270.824 \\
(5.45)^{* *}\end{array}$ & $\begin{array}{l}343.300 \\
(6.32)^{* *}\end{array}$ & \\
\hline & $\begin{array}{l}\mathrm{N}=200 \\
\mathrm{R}^{2} .79\end{array}$ & $\begin{array}{l}\mathrm{N}=200 \\
\mathrm{R}^{2} .83\end{array}$ & \\
\hline
\end{tabular}




\section{FIGURE 1}

Marginal Effect of Court Professionalism on Litigation As Liberalism Changes

Dependent Variable: Tort Litigation

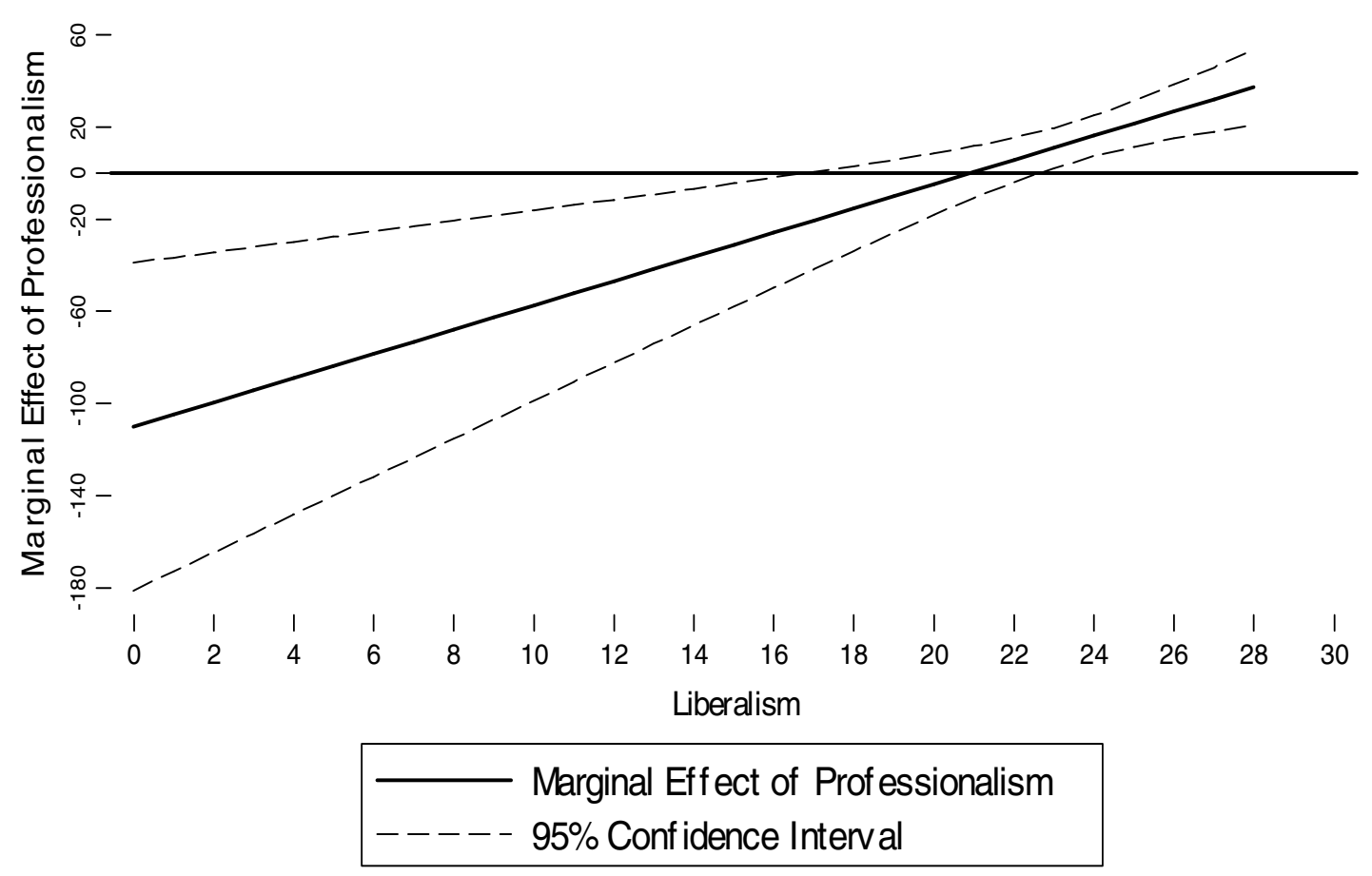




\section{FIGURE 2}

Marginal Effect of Judicial Elections on Litigation As Liberalism Changes

Dependent Variable: Tort Litigation

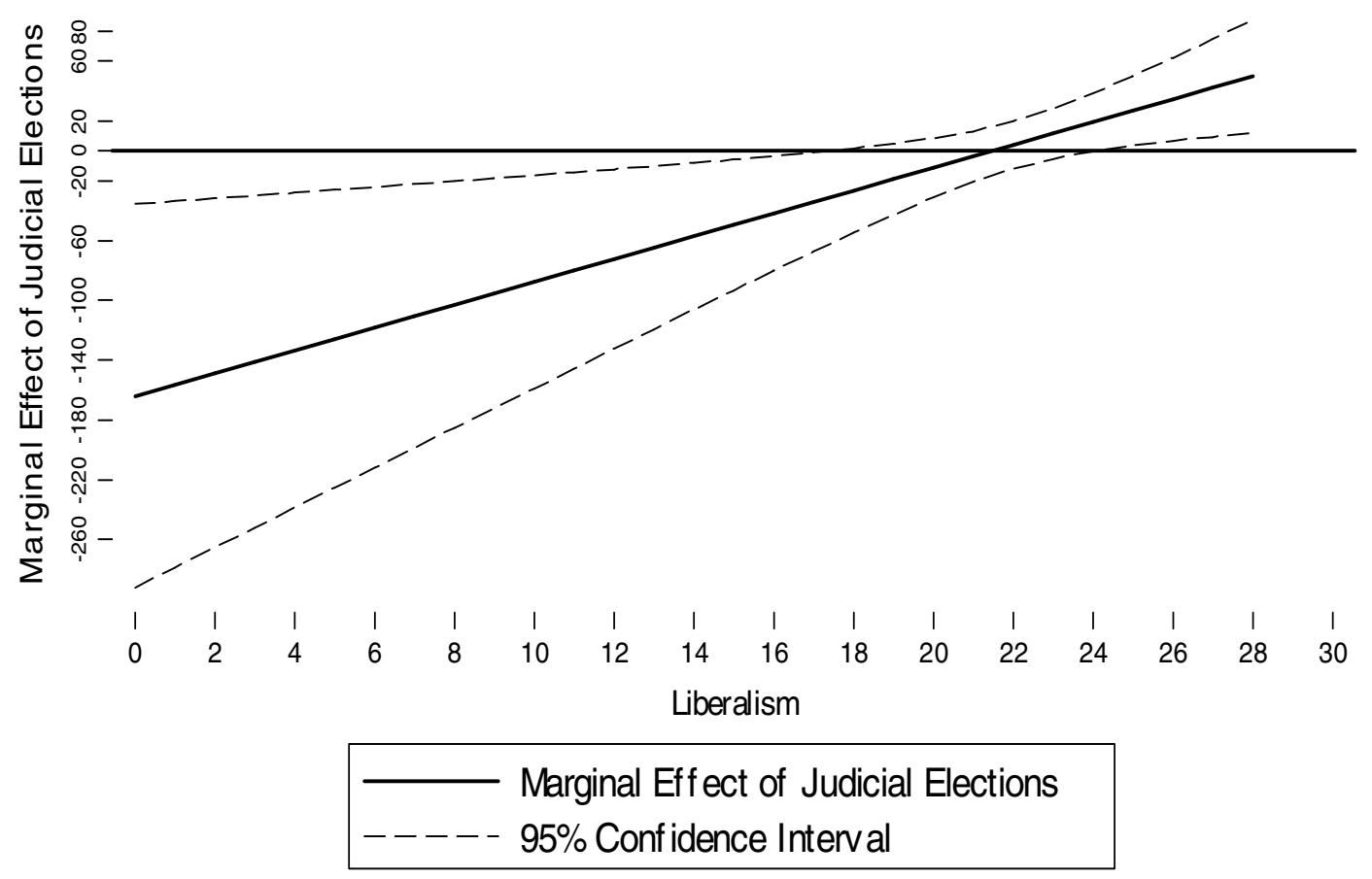




\section{FIGURE 3}

Marginal Effect of Professionalism on Litigation As Liberalism and Elections Change

Dependent Variable: Tort Litigation

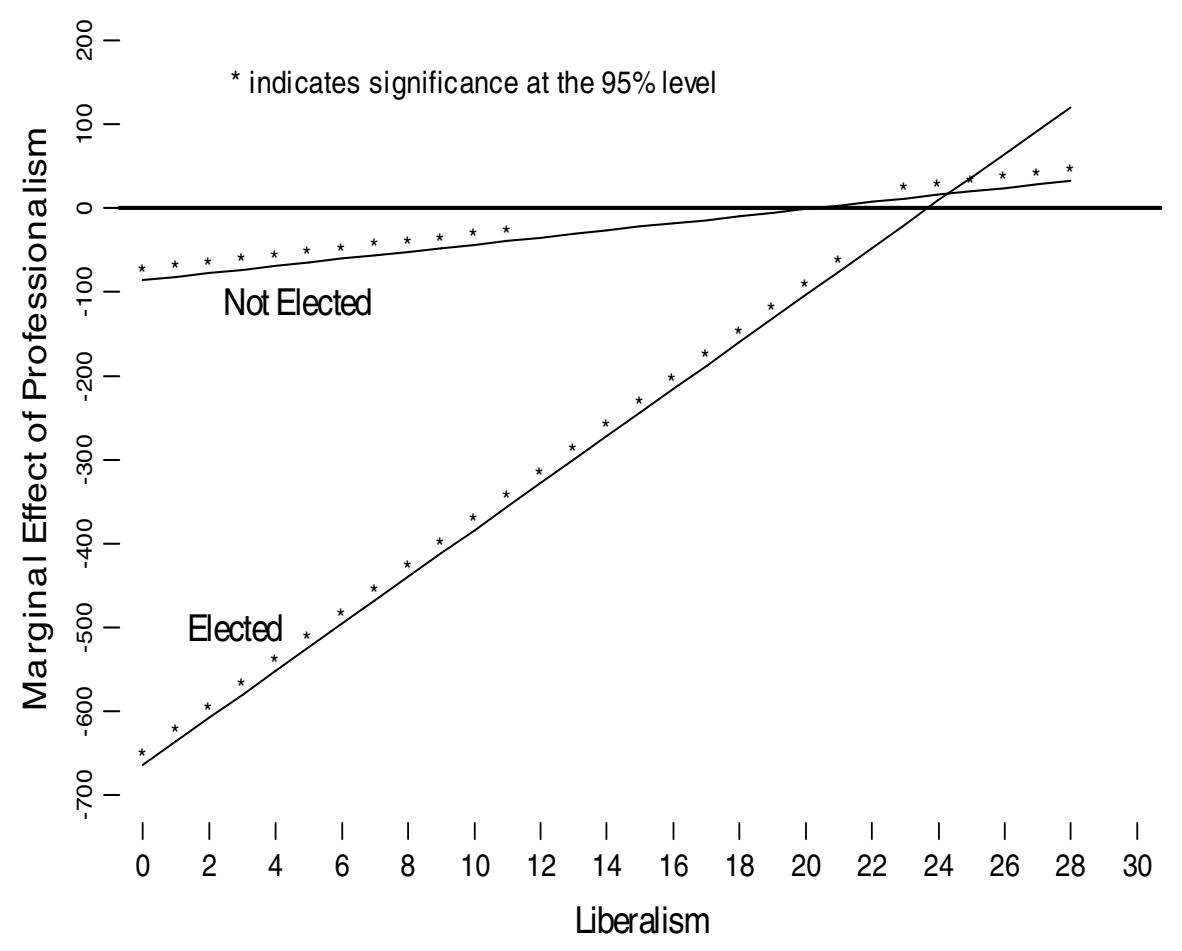

